\title{
Morphophysiological Adaptation Aspects of Different Haloxylon aphyllum (Chenopodiaceae) Genotypes Along a Salinity Gradient ${ }^{1}$
}

\author{
E. V. Shuyskaya ${ }^{a *}$, E. V. Li ${ }^{b}$, Z. F. Rahmankulova ${ }^{a}$, N. A. Kuznetsova ${ }^{a}$, \\ K. N. Toderich ${ }^{c * *}$, and P. Yu. Voronin ${ }^{a}$ \\ ${ }^{a}$ K. A. Timiryazev Institute of Plant Physiology Russian Academy of Science, Botanicheskaya 35, Moscow, 127276 Russia \\ ${ }^{b}$ Samarkand State University, University Boulevard, 15, Samarkand, 140100 Uzbekistan \\ ${ }^{c}$ International Center for Biosaline Agriculture (ICBA), Osye st., 6A, Tashkent, 100000 Uzbekistan \\ e-mail:*evshuya@mail.ru;**k.toderich@cgiar.org; salev85@rambler.ru
}

\begin{abstract}
The seedlings of Haloxylon aphyllum from seeds with different genetic characteristics, which were collected in three natural subpopulations along a soil salinity gradient, were investigated. The plants grown under various levels of $\mathrm{NaCl}(0-300 \mathrm{mM})$ differed in the shoot length, the relative growth rate (calculated for fresh and dry biomass), as well as ions and proline contents. The heterozygous genotypes of xerohalophytic $H$. aphyllum have shown significant advantages in their productivity and sustainability under moderate and high salinity.
\end{abstract}

Keywords: Haloxylon àphyllum, genotypes, salinity, biomass

DOI: $10.1134 / \mathrm{S} 1067413614030114$

Due to the increasing aridity of climate the most important task of modern science and practice is the mobilization of genetic resources of halophytes through creation of gene bank, evaluation and selection of valuable fodder, food, medicinal and oil species followed by their introduction into high-productive arid farming production system (Koyro et al., 2011). The arid areas differ by level of soils salinity and the understanding of physiological and biochemical mechanisms of adaptive responses of different ecological groups of halophytes and salt tolerant crops to saline environments are crucial.

Haloxylon aphyllum(Minkw.) Iljin, Chenopodiaceae (black saxaul) is one of the main desert landscaping edificators and economically most important rangeland halophyte used for stabilization of sandy soils, as well as forage and woody fuel source for the local people in the Turan Desert (Central Asia). This tree-like aphyllous shrub with succulent photosynthetic shoots can grow on topographic depressions on sand and gypsum substrates with varying level of salinity (Nikitin, 1966; Gintzburger et al., 2003).

In one of the previous studies (Shuyskaya et al., 2012; Li et al., 2013) it was shown that under natural conditions $H$. aphyllum produces two types of seeds: large seeds with accelerated rate of germination, and $21-28 \%$ of heterozygosity; also small seeds with longterm seed germination rate, and $3-12 \%$ of heterozy-

\footnotetext{
${ }^{1}$ The article was translated by the authors.
}

gosity. Small seeds are produced by $H$. aphyllum under suboptimal conditions: low $(0-0.05 \mathrm{mmol} \mathrm{Na} / \mathrm{g})$ and high $(0.3-0.5 \mathrm{mmol} \mathrm{Na} / \mathrm{g})$ soil salinity, while large seeds were found under optimal conditions for this xerohalophytic species $\left(0.05-0.1 \mathrm{mmol} \mathrm{Na}^{+} / \mathrm{g}\right)$. Thus, in optimum conditions the selection occurs in favor of heterozygotes (which are more "successful" because the heterozygosity degree correlates with the plant fitness (Mandak et al., 2006)). The selection of homozygotes is mostly observed in suboptimal conditions and it's possible that these genotypes are more successful in such conditions.

Similar results were obtained for other Chenopodiaceae species (Mandak et al., 2006). For example, seeds of Atriplex tatarica L. germinated under suboptimal conditions are homozygous, while heterozygous plants occur under optimum conditions. Moreover, a positive correlation was found between the degree of heterozygosity and the weight of shoots and reproductive organs (Mandak et al., 2006). There is an evidence (Cabin et al., 1997) that germination of seeds with different quality and seedling survival under certain conditions can play an important role in forming and maintaining the genetic structure of natural populations and species evolution.

A number of studies (Houle, 1989; Lonn et al., 1996) showed that allozyme heterozygosity is a good indicator of population fitness and high adaptive potential. Some authors (Reed, Frankham, 2003) state that such molecular data reflects only a small part 
of the genome, and therefore may not be a good indicator of adaptive genetic differences. But, at the same time other researchers proved that at least some enzymes can be under the direct selection (Mitton, Gran, 1984). For example, allozymes of the phosphoglucose isomerase (Pgi) have been shown to associate with the oxygen availability (Zangerl, Bazzaz, 1984), soil type (Nevo et al., 1981), soil moisture and pH level (Prentice et al., 1995) and finding seeds in different habitats (Lonn et al., 1996). Previously we showed that the Got-2 locus might be taken as a genetic marker for various types of $H$. aphyllum seeds. Seeds of the second type are characterized by predominance of $(84-100 \%)$ homozygous genotypes of Got-2 locus, whereas seeds of the first type have only (100\%) heterozygous genotypes at this locus (Shuyskaya et al., 2012). However, some questions remain unclear: 1 -would $H$. aphyllum seeds of first type (heterozygote at Got-2) reliably produce more productive plants in optimal water-salt conditions? 2-would these plants also turn out to be highly productive in suboptimal water-salt conditions? 3 - to what extent the plants grown from seeds of the second type (homozygote at Got-2) would be stable and productive in suboptimal water-salt conditions?

The primary purpose of this paper is to study the morphophysiological features of different genotypes of Haloxylon aphyllum related to their adaptation to low and high soil salinity.

\section{MATERIAL AND METHODS}

The seeds of $H$. aphyllum were collected in Ecocenter "Djeiran", Southwest Kyzylkum, Bukhara region, Uzbekistan $\left(39^{\circ} 34^{\prime} \mathrm{N}, 64^{\circ} 42^{\prime} \mathrm{E}\right)$. Three sites with similar soil structure (sands), but with different levels of salinity $\left(0-0.05,0.05-0.1\right.$ and $\left.0.25-0.3 \mathrm{Na}^{+} \mathrm{mmol} / \mathrm{g}\right)$ were chosen into the population.

Seeds of the first type collected in the site with moderate soil salinity $\left(0.05-0.1 \mathrm{Na}^{+} \mathrm{mmol} / \mathrm{g}\right)$ were $8.0 \pm 0.2 \mathrm{~mm}$ in size. These seeds had a relatively high level of genetic polymorphism: the average observed heterozygosity was $12.7 \%$, heterozygosity of Got-2 locus-100\%. Seeds of the second type collected in sites with soil salinity $0-0.05$ and $0.25-0.3 \mathrm{Na}^{+} \mathrm{mmol} / \mathrm{g}$ are characterized by smaller size: $6.4 \pm 0.1$ and $7.0 \pm 0.2 \mathrm{~mm}$, respectively. As well as they had lower level of genetic polymorphism: the average observed heterozygosity was $6.5 \%$, heterozygosity of Got-2 locus- $0 \%$. The average heterozygosity was calculated using the allozyme analysis data (Shuyskaya et al., 2012) of eight enzyme systems: GOT (E.C. 2.6.1.1), DIA (E.C. 1.6.99), GDH (E.C. 1.4.1.2), SOD (1.15.1.1), G6PD (E.C. 1.1.1.49), 6PGD (1.1.1.44), MDH (E.C. 1.1.1.37), Me (E.C. 1.1.1.40). Seeds from 10-25 individual plants were collected in each site. Distance between plants was $5-50 \mathrm{~m}$, between sites $-1-5 \mathrm{~km}$.

Seeds were germinated in distilled water. 4-6 dayold seedlings were transplanted to perlite, irrigated with $25 \%$ nutrient solution Hoagland. In nutrient solution the following concentrations $\mathrm{NaCl}$ : $100 \mathrm{mmol}$ (optimal salinity), 50, 200 and $300 \mathrm{mmol}$ (suboptimal salinity) have been created in accordance with the natural conditions. Then 35 day-old plants were transferred to the experimental solutions (irrigated perlite). $25 \%$ Hoagland nutrient solution was used as a control. The experiment lasted for 18 days.

The following parameters were evaluated: change fresh and dry biomass $(W)$, relative growth rate ( $\mathrm{RGR}=\Delta W / W^{*} \Delta t$, where $\Delta W$-biomass growth, $W$-initial biomass, $\Delta t$-day) in photosynthetic shoots in all groups studied plants. The relative water content, chlorophyll and proline, as well as the accumulation of sodium $\left(\mathrm{Na}^{+}\right)$and potassium $\left(\mathrm{K}^{+}\right)$ions in photosynthetic organs were measured.

The plant samples were dried for two days at $80^{\circ} \mathrm{C}$ for measuring the dry biomass and relative water content. The content of $\mathrm{Na}^{+}$and $\mathrm{K}^{+}$ions were determined in the water extract of $100 \mathrm{mg}$ sample using an atomic absorption spectrometer (Hitachi 207, Japan). Free proline was determined using acid ninhydrin reagent according to Bates (Radyukina et al., 2011). And chlorophyll content was extracted in $96 \%$ ethyl alcohol (Vernon, 1960) and determined spectrophotometrically. The results are shown expressed as mkg or mg or mmol g ${ }^{-1}$ (dry mass).

The measurements were performed at list three times, and the means and calculated standard errors $( \pm \mathrm{SE})$ are calculated using Sigma Plot 12.0 statistical program. Comparisons of parameters were made between treatments using analysis of variance (ANOVA) with Tukey test for pairwise comparison. Differences were considered significant at $p<0.05$.

\section{RESULTS}

Growth is an integral physiological characteristic. Therefore in order to understand the influence of salinity level on different saxaul genotypes (in model experiments) the following morphological parameters were selected: length of shoots, accumulation and relative growth rate of the fresh and dry biomass (Fig. 1). Seeds collected from three genetically different subpopulations in various saline soils environments were planted at different levels of $\mathrm{NaCl}(50-300 \mathrm{mmol})$. The plants grown from these seeds appeared to differ in the length of shoots and the rate of accumulation of fresh biomass. The highest values of these parameters were observed in plants of the first type (heterozygous genotype) grown in conditions with low salinity level (100 mmol). The lowest values of these parameters belonged to plants of the second type (homozygous genotype) grown under high salinity $(300 \mathrm{mmol})$ (Figs. 1a, 1b).

The growth parameters of $H$. aphyllum were analyzed based on the contents of $\mathrm{NaCl}$ in the nutrient solution. The high positive correlation was revealed between the dry biomass growth rate of plants with heterozygous genotype and salinity levels of nutrient 
(a)

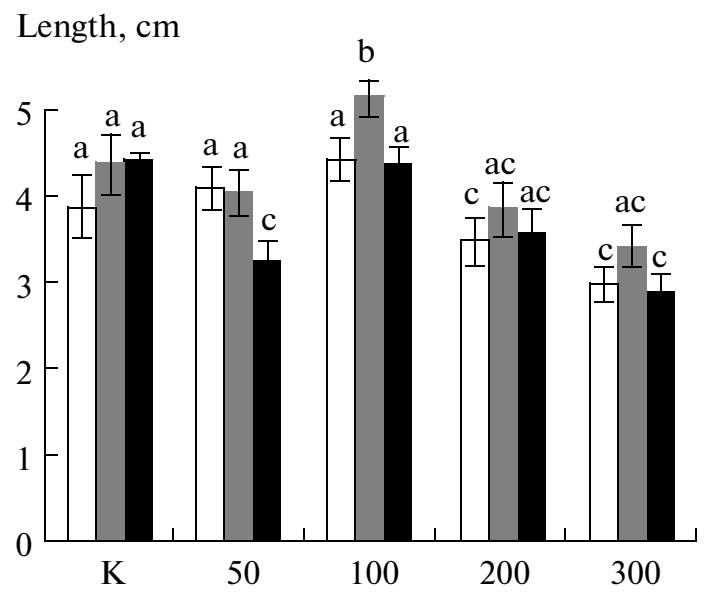

(c)

Dry biomass, mg (b)

RGR, fresh biomass, $\mathrm{mg} /(\mathrm{mg} \mathrm{h})$

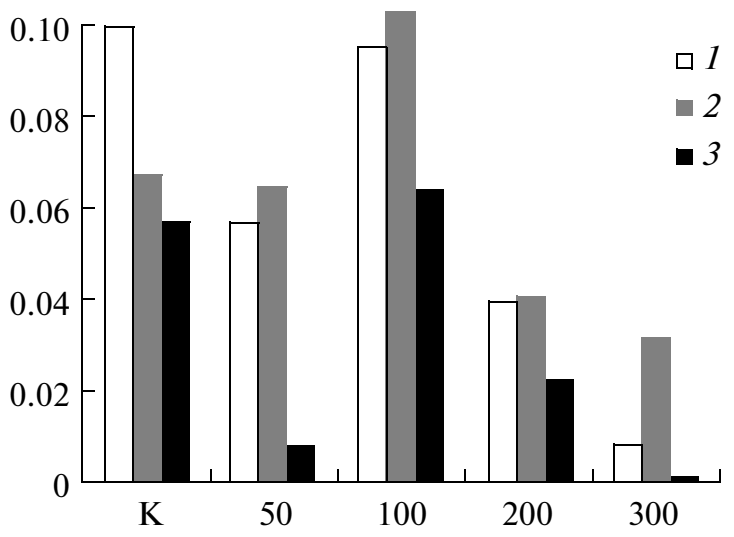

(d)

RGR, dry biomass, $\mathrm{mg} /(\mathrm{mg} \mathrm{h})$

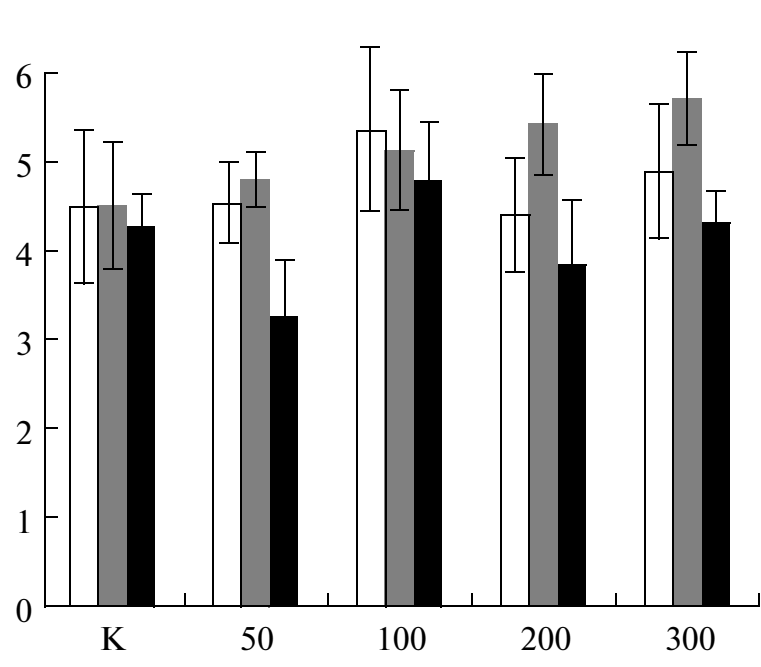

Salinity level, $\mathrm{mM}$

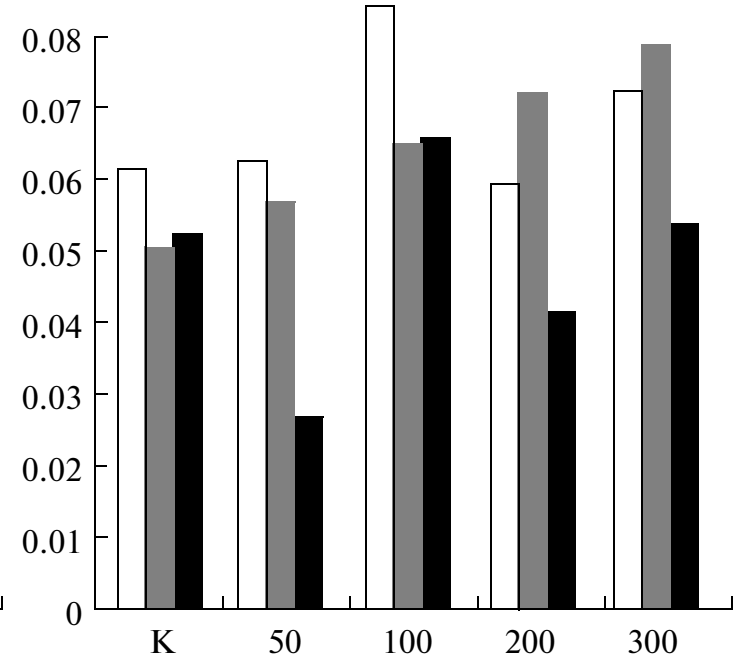

Salinity level, $\mathrm{mM}$

Fig. 1. Effect of salt $(\mathrm{NaCl})$ treatments on (a) length of seedlings, (b) relative growth rate (RGR) of fresh biomass, (c) dry biomass and (d) RGR of dry biomass in shoots of H. aphyllum. 1-low salinity, 2-moderate salinity, 3-high salinity. Letters above the bars (on Fig. a and c) represent significant differences at the $p<0.05$ (Tukey's pairwise comparison). The absent of letters above the bars indicate insignificant differences at the $p<0.05$. RGR was calculated using mean values of fresh and dry biomass.

solution $(r=0.98, p<0.05)$. No correlation was found for homozygous plants (see Fig. 1c).

The water content in photosynthetic shoots of all plant groups negatively correlated with the level of salinity (Fig. 2a). The highest values of this parameter occurred at low salinity $(100 \mathrm{mmol} \mathrm{NaCl})$. Our observations showed that at high salt concentrations (200$300 \mathrm{mmol}$ ) the water content in shoots decreased by $40 \%$.

The content of $\mathrm{Na}^{+}$and $\mathrm{K}^{+}$ions and their ratio in $H$. aphyllum shoots were investigated. A close positive correlation was found between the salinity level of nutrient solution and $\mathrm{Na}^{+}$ions content in the aboveground biomass of heterozygous $(r=0.77, p<0.05)$ and homozygous $(r=0.8-0.9, p<0.05)$ plants and reverse connection with $\mathrm{K}^{+} / \mathrm{Na}^{+}$ratio $(r=-0.77 \ldots-0.84, p<$ $0.05)$ in all plant groups.

Negative correlation between the relative growth rate of dry biomass and $\mathrm{K}^{+} / \mathrm{Na}^{+}$ratio $(r=-0.89, p<$ 0.05 ) was identified in plants with heterozygous genotype. No such correlation was found for homozygous plants.

The $\mathrm{K}^{+}$content and $\mathrm{K}^{+} / \mathrm{Na}^{+}$ratio was $1.5-2$ times higher in heterozygous plants than in homozygous. The highest values of these parameters were observed in the control plants (Figs. 2c, 2d). 
(a)

Relative water content, g/g dry biomass

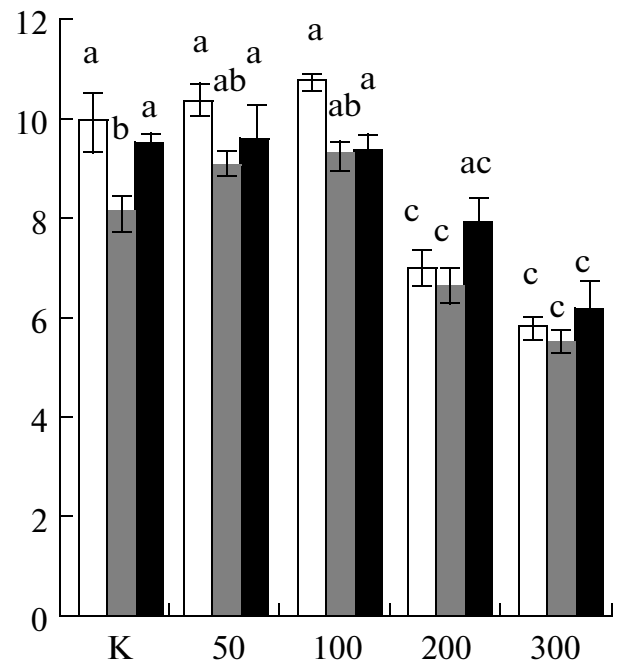

(c)

$\mathrm{K}, \mathrm{mmol} / \mathrm{g}$ dry biomass

b

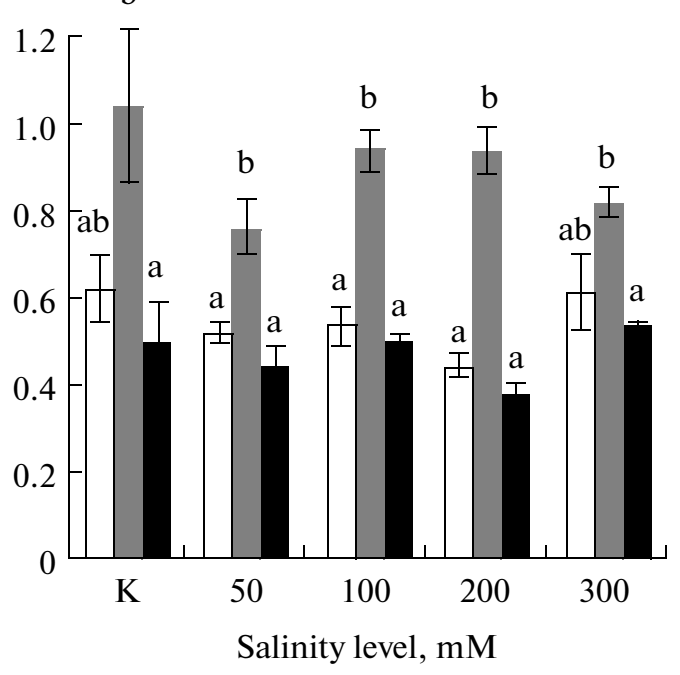

(b)

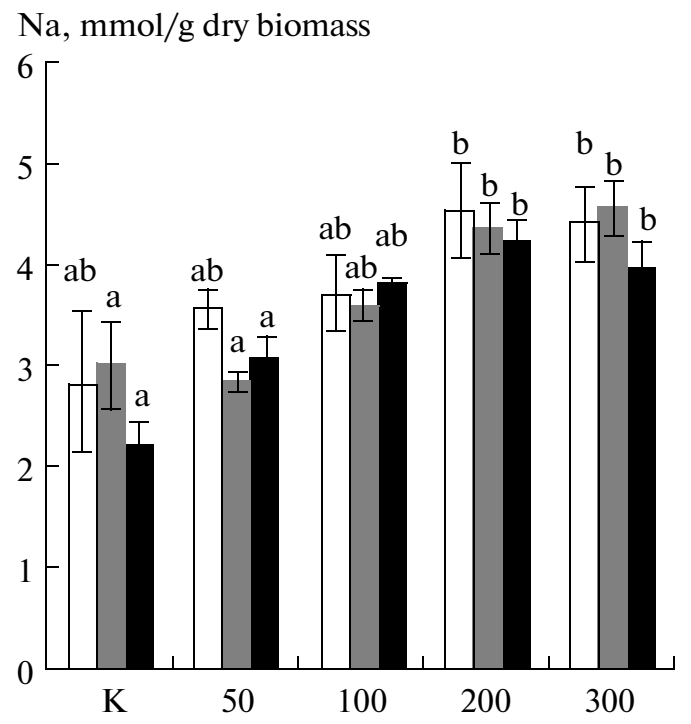

(d)

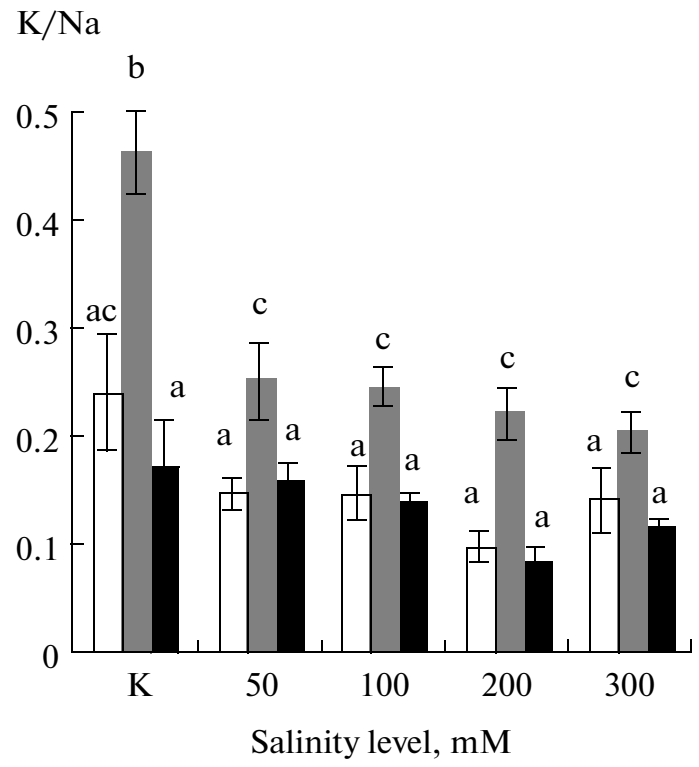

Fig. 2. Effect of salt $(\mathrm{NaCl})$ treatments on (a) relative water content, (b) $\mathrm{Na}^{+}$, (c) $\mathrm{K}^{+}$and (d) $\mathrm{K}^{+} / \mathrm{Na}^{+}$ratio in shoots of $H$. aphyllum. The values are means ( $\pm \mathrm{SD}, n=6$ for values of relative water content, $n=3$ for values of ions content). The descriptions of other symbols are similar to Fig. 1 .

The course of experiments examined the influence of salinity on such biochemical parameters as proline content, chlorophyll $a$ and $b$ in different saxaul genotypes. The lowest proline content was found under low salinity (100 mmol NaCl) in all studied groups (Fig. 3a). Significant differences in proline content were shown for heterozygotes: 1 -between control plants and plants grown under $100 \mathrm{mmol} \mathrm{NaCl}$ treatment $(F=$ $7.4 ; p<0.01), 2$ - between plants grown under different levels of salinity at $100 \mathrm{mmol}$ and $300 \mathrm{mmol} \mathrm{NaCl}$ $(F=7.4 ; p<0.01)$, and 3 - between control plants and plants grown under $300 \mathrm{mmol} \mathrm{NaCl}$ treatment $(F=$ $10.5 ; p<0.01)$. The highest content of proline was noted in plants grown under $300 \mathrm{mmol} \mathrm{NaCl}$ treatment in homozygous plants from the site with low soil salinity. There is significant differences $(F=7.8 ; p<$ $0.01)$ between this group of plants under $100 \mathrm{mmol}$ and $300 \mathrm{mmol} \mathrm{NaCl}$ treatments.

At last, significant differences were not revealed in chlorophyll content between all investigated plant groups. 
(a)

Proline, $\mathrm{mkg} / \mathrm{g}$ fresh biomass

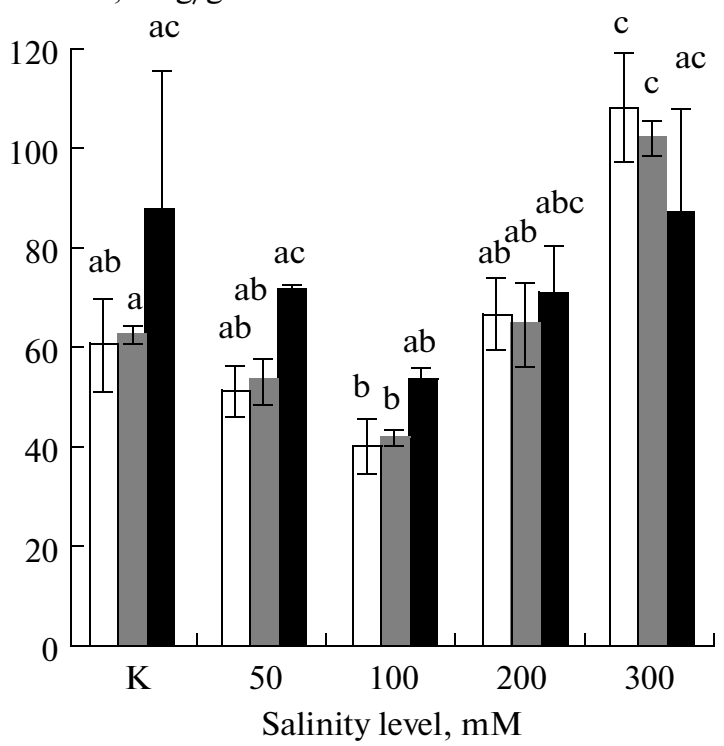

(b)

$\mathrm{Ca}+\mathrm{b}, \mathrm{mg} / \mathrm{g}$ fresh biomass

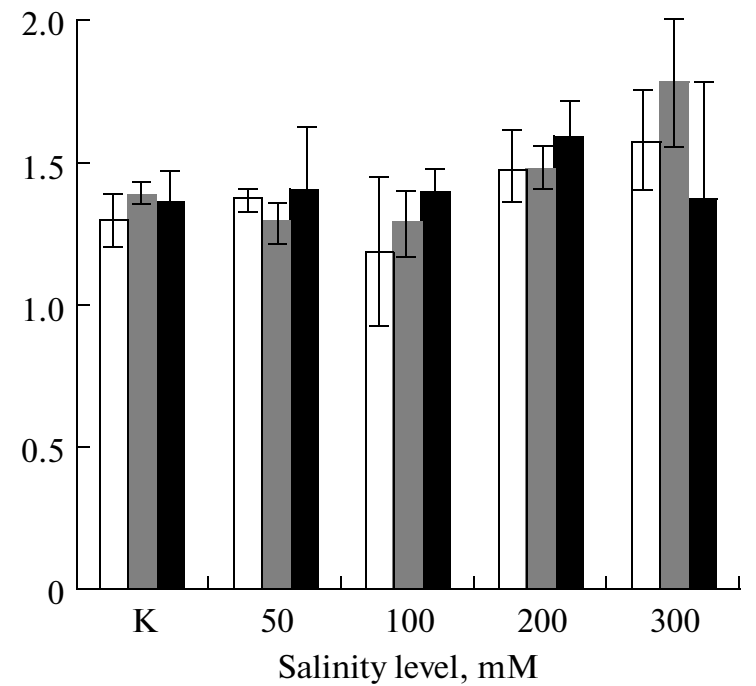

Fig. 3. Effect of salt $(\mathrm{NaCl})$ treatments on (a) proline and (b) chlorophyll contents $(\mathrm{Ca}+\mathrm{b})$ in shoots of H. aphyllum. The values are means $( \pm \mathrm{SD}, n=6)$. The descriptions of other symbols are similar to Fig. 1 .

\section{DISCUSSION}

Despite the fact that the halophytes are well adapted to salinity, the level of their salt tolerance is strongly dependent on the species, ecotype and the stage of development (Megdiche et al., 2007; Eshghizaden et al., 2012). Most of the halophytes belong to the Chenopodiaceae family, which includes about 550 species with different mechanisms of salt tolerance (Roohi et al., 2011). Our results indicate that based on analysis of some morphological features there are differences not only on interspecies level but also within intraspecific varieties.

Genetic variation in natural populations can occur partially due to the ability of individual genotypes to grow locally in the specific environmental conditions. If the correlation between growth and heterozygosity really exists, the process of selective growth can affect not only the genetic variability but also more intense growth of certain genotypes under specific environments (Mandak et al., 2006). As was described above, the differences were revealed between growth characteristics (length of shoots, growth rate and accumulation of fresh biomass) of heterozygous and homozygous genotypes of $H$. aphyllum under different levels of salinity, which appeared to be consistent with the data for Atriplex tatarica (Mandak et al., 2006). Our findings and literature data suggest that heterozygous genotypes are characterized by large values of previously mentioned parameters at low salinity $(100 \mathrm{mmol}$ $\mathrm{NaCl}$ ) (Figs. 1a, 1b).

Answering the question of scientific debate regarding the necessity of salts for growth and development of halophytes (Grigore et al., 2012), we can say that the data of the seedling length, the relative growth rate of fresh biomass, and proline content (Figs. 1a, 1b, 3a) in $H$. aphyllum plants demonstrates that xerophytes require low dose of salt content in the nutrient solution for the better survival. The optimum salt content for $H$. aphyllum is $100 \mathrm{mmol} \mathrm{NaCl}$, and it is more pronounced in heterozygous genotypes.

Ability of halophytes to live, grow and reproduce at a relatively high salt content in soil or nutrient solution is related to the presence of specific protection mechanisms. The maintenance of low concentrations of ions in the cytoplasm (for avoiding the toxic effect of ions) is one part of strategy of ionic and osmotic homeostasis. Other part represents the ability to maintain a gradient of water potential upward in the system soil-root-shoots (Balnokin et al., 2005; Roohi et al., 2011).

In the literature the high sodium accumulation in plant cells is explained by the osmotic effect of salinity which reduces the water content in the cytosol and leading to rapidly increasing the concentration of dissolved substances. And ion effect is caused by the influx of $\mathrm{Na}^{+}$by $\mathrm{K}^{+} / \mathrm{Na}^{+}$-channels, which also increase the intracellular concentration of salt (Allakhverdiev et al., 2000). Under normal conditions the systems of active transport maintain constant osmotic pressure in the cell and the optimum concentration of $\mathrm{K}^{+}$ions, and pump out $\mathrm{Na}^{+}$ions. Toxic effect of salinity is directly linked to the fact that $\mathrm{Na}^{+}$ions replace $\mathrm{K}^{+}$ions in the cytosol (Carden et al., 2001). The ability of plant cells to maintain a stable level of cytosolic $\mathrm{K}^{+}$ in the medium with high concentration of $\mathrm{Na}^{+}$is a key 
factor in determining the ability to tolerate salt stress because potassium is an activator of many enzymes in plant cells (Maathuis, Amtmann, 1999). In our experiments, plants with heterozygous genotypes were characterized by the highest values of potassium content under all levels of salinity (Fig. 2). The interesting characteristic feature of the heterozygous plant group was a steady growth of the dry biomass rate under increasing salinity levels (in the studied range of $0-300 \mathrm{mmol} \mathrm{NaCl})(r=$ $0.98, p<0.05)$. Thus, this genotype showed resistance to high salinity (Fig. 1c, 1d). The positive correlation between the relative growth rate of dry biomass and sodium content $(r=0.7, p<0.05)$ and the negative correlation with the $\mathrm{K}^{+} / \mathrm{Na}^{+}$ratio $(r=-0.9, p<0.05)$ were found in plants of this group. And as shown by other authors, the ratio of $\mathrm{K}^{+} / \mathrm{Na}^{+}$decreases with the increasing salt stress (El-Iklil et al., 2002), and precisely that $\mathrm{K}^{+} / \mathrm{Na}^{+}$ratio (and not just the absolute concentration of $\mathrm{Na}^{+}$) in the cytosol is being a critical indicator of the stress level in plants, as it was indicated early (Carden et al., 2003).

A change of ions content under stress of high salt concentrations might be closely associated with the accumulation of free proline in the plant cells. Japanese scientists (Okuma et al., 2002) suggested that intracellular proline might be inducing the inhibition of enzyme activity by reducing the content of free radicals in cells with decreasing $\mathrm{K}^{+} / \mathrm{Na}^{+}$ratio. They showed a negative correlation between $\mathrm{K}^{+} / \mathrm{Na}^{+}$ratio and proline accumulation in suspension of tobacco cells already after 3-5 days from starting the cultivation.

It is known that proline is primarily a powerful osmoprotectant, and thus the intensity of its biosynthesis is enhanced, and degradation is reduced under salinity (Szabados, Savoure, 2010). As our data analysis showed, the lowest proline content was associated with the nutrient solution of $100 \mathrm{mmol} \mathrm{NaCl}$, hence it was marked as the optimal salt concentration for H. aphyllum. Almost 2 times increase of proline content under higher salinity $(300 \mathrm{mmol} \mathrm{NaCl})$ contributed to the increase of dry biomass (Fig. 1g) and the biosynthesis of chlorophyll (Fig. 3), which confirms its protector role (Szabados, Savoure, 2010; Roohi et al., 2011).

Plants grown from seeds of the second type, which were collected from the sites with low and moderate salinity levels $(0-100 \mathrm{mmol} \mathrm{NaCl})$, were characterized by the highest values of relative growth rate of dry biomass and the lowest content of proline. While plants from seeds of haloxylon subpopulation collected from the site with hypersaline soil were less productive under high salinity (Fig. 1b). In natural populations the selection acts under pressure of certain (single or multiple) stress factors. It's possible that at least two stress factors act in case of H. aphyllum - soil salinity and water deficit. Instability and variety of growth and biochemical characteristics of plants grown from seeds of the second type (homozygous) in experimental conditions indicated that salinity is not a determining selective factor. Thus it can be assumed that the selection occurs under the action of other factors, such as deficit of available water.

The data indicates that the plants grown from the seeds of the first type (heterozygote at Got-2) are more productive (calculated as per biomass accumulation) in both optimal and suboptimal conditions (high salinity). Plants grown from the seeds of the second type (homozygote at Got-2) in suboptimal conditions were not characterized by stability and high productivity, as previously assumed.

In summary, the studied genotypes appeared to differ in their morpho-physiological and biochemical characteristics, which indicate that the different mechanisms of salt tolerance are developed allowing the successful survival and dominance in plant communities. The heterozygous genotypes of xerohalophyte $H$. aphyllum have advantages in terms of productivity and sustainability under moderate and high salinity.

The work was supported by the RAS Presidium (Program No 4, project 4.6.3.) and the Russian Foundation for Basic Research (project no. 12-04-97023_r_a).

\section{REFERENCES}

Allakhverdiev, S.I., Sakamoto, A., Nishiyama, Y., et al., Ionic and osmotic effects of $\mathrm{NaCl}$-induced inactivation of photosystems I and II in Synechococcus sp., Plant Physiol., 2000, vol. 123, pp. 1047-1056.

Balnokin, Yu.V., Kotov, A.A., Myasoedov, N.A., Khailova, G.F., Kurkova, E.B., Lun'kov, R.B., and Kotova, L.M., Involvement of long-distance $\mathrm{Na}^{+}$transport in maintaining water potential gradient in the medium-root-leaf system of a halophyte Suaeda altissima, Russ. J. Plant Physiol., 2005, vol. 52, no. 4, pp. 489-496.

Cabin, Y.J., Evans, A.S., and Mitchell, R.J., Genetic effect of germination timing and environment: An experimental investigation, Evolution, 1997, vol. 51, pp. 1427-1434.

Carden, D.E., Diamond, D., and Miller, A.J., An improved $\mathrm{Na}^{+}$-selective microelectrode for intracellular measurements in plant cells, J. Exp. Bot., 2001, vol. 52, pp. 13531359.

Carden, D.E., Walker, D.J., Flowers, T.J., et al., Single-cell measurements of the contributions of cytosolic $\mathrm{Na}^{+}$and $\mathrm{K}^{+}$ to salt tolerance, Plant Physiol., 2003, vol. 131, pp. 676683.

El-Iklil, Y., Karrou, M., Mrabet, R., et al., Salt stress effect on metabolite concentrations of Lycopersicon esculentum and Lycopersicon sheesmanii, Can. J. Plant Sci., 2002, vol. 82, no. 1, pp. 177-183.

Eshghizadeh, H., Kafi, M., and Nezami, A., The mechanisms of salinity tolerance in the xero-halophyte blue panicgrass (Panicum antidotale Retz), Not. Sci. Biol., 2012, vol. 4, no. 2, pp. 59-64.

Gintzburger, G., Toderich, K.N., Mardonov, B.K., et al., Rangelands of the Arid and Semi-arid Zones in Uzbekistan, Monpellier: CIRAD, 2003. 
Grigore, M., Villanueva, M., Boscaiu, M., et al., Do halophytes really require salts for their growth and development? An experimental approach, Not. Sci. Biol., 2012, vol. 4, no. 2, pp. 23-29.

Houle, D., Allozyme associated heterosis in Drosophila melanogaster, Genetics, 1989, vol. 123, pp. 789-801.

Koyro, H-W., Ajmal Khan, M., and Lieth, H., Halophytic crops: A resource for the future to reduce the water crisis?, Emir. J. Food Agric., 2011, vol. 23, no. 1, pp. 1-16.

Li, E.V., Shuiskaya, E.V, Matyunina, T.E., and Toderich,K.N., Conjugative development of reproductive structures of Haloxylon aphyllum (Minkw.) Iljin along the soil salinity gradient, Arid. Ecosyst., 2013, no. 2, pp. 71-76.

Lonn, M., Prentice, H.C., and Bengtsson, K., Genetic structure, allozyme-habitat associations, and reproductive fitness in Gypsophila fastigiata (Caryophyllaceae), Oecologia , 1996, vol. 106, pp. 308-316.

Maathuis, F.J.M. and Amtmann, A., $\mathrm{K}^{+}$nutrition and $\mathrm{Na}^{+}$ toxicity: The basis of cellular $\mathrm{K}^{+} / \mathrm{Na}^{+}$ratios, Ann. Bot., 1999, vol. 84, pp. 123-133.

Mandak, B., Bimova, K., and Plackova, I., Genetic structure of experimental populations and reproductive fitness in a heterocarpic plant Atriplex tatarica (Chenopodiaceae), Am. J. Bot., 2006, vol. 93, no. 11, pp. 1640-1649.

Megdiche, W., Ben Amor, N., Debez, A., et al., Salt tolerance of the annual halophyte Cakile maritima as affected by the provenance and the developmental stage, Acta Physiol. Planta, 2007, vol. 29, pp. 375-384.

Mitton, J.B. and Gran, M.C., Associations among protein heterozygosity, growth rate, and developmental homeostasis, Ann. Rev. Ecol. Syst., 1984, vol. 15, pp. 479-499.

Nevo, E., Brown, A.H.D., Zohary, D., et al., Microgeographic edaphic differentiation in allozyme polymorphism of wild barley (Hordeum spontaneum, Poaceae), Plant Syst. Evol., 1981, vol. 138, pp. 287-292.
Nikitin, S.A., Drevesnaya $i$ kustarnikovaya rastitel'nost' pustyn' SSSR (Tree and Shrub Vegetation in Deserts of the Soviet Union), Moscow: Nauka, 1966.

Okuma, E., Soeda, K., Fukuda, M., et al., Negative correlation between the ratio of $\mathrm{K}^{+}$to $\mathrm{Na}^{+}$and proline accumulation in tobacco suspension cells, Soil Sci. Plant Nutr., 2002, vol. 48, no. 5, pp. 753-757.

Prentice, H.C., Lonn, M., Lefkovitch, L.P., et al., Associations between allele frequencies in Festuca ovina and habitat variation in the alvar grasslands on the Baltic island of Öland, J. Ecol., 1995, vol. 83, pp. 391-402.

Radyukina, N.L., Ivanov, Yu.V., and Shevyakova, N.I., Methods for quantitative analysis of reactive oxygen species, low-molecular-weight antioxidants, and basic antioxidant enzyme activities, in Molekulyarno-geneticheskie $i$ biokhimicheskie metody $v$ sovremennoi biologii rastenii (Molecular Genetic and Biochemical Methods in Modern Plant Biology), Kuznetsov, Vl.V., Kuznetsov, V.V., and Romanov, G.A., Eds., Moscow: Binom, 2011, pp. 347-365. Reed, D.H. and Frankham, R., Correlation between fitness and genetic diversity, Conserv. Biol., 2003, vol. 17, pp. 230237.

Roohi A., Nazish B., Nabgha-e-Amen, et al., Critical review on halophytes: Salt tolerant plants, J. Med. Plants Res., 2011, vol. 5, no. 33, pp. 7108-7118.

Shuyskaya, E.V., Gismatullina, L.G., Toderich, K.N., et al., Genetic differentiation of black saxaul, Haloxylon aphyllum (Chenopodiaceae), along a soil salinity gradient in the Kyzylkum Desert, Russ. J. Ecol., 2012, no. 4, pp. 302-306.

Szabados, L., Savouré, A., Proline: A multifunctional amino acid, Trends Plant Sci., 2010, vol. 15, no. 2, pp. 89-97. Vernon, L.P., Spectrophotometric determination of chlorophylls and pheophytins in plant extracts, Anal. Chem., 1960, vol. 32, pp. 1144-1150.

Zangerl, A.R. and Bazzaz, F.A., Niche partitioning between two phosphoglucoisomerase genotypes in Amaranthus retroflexus, Ecology, 1984, vol. 65, pp. 218-222. 